\title{
"Portfolio optimization of bank credits with interval returns: Empirical evidence from Iran"
}

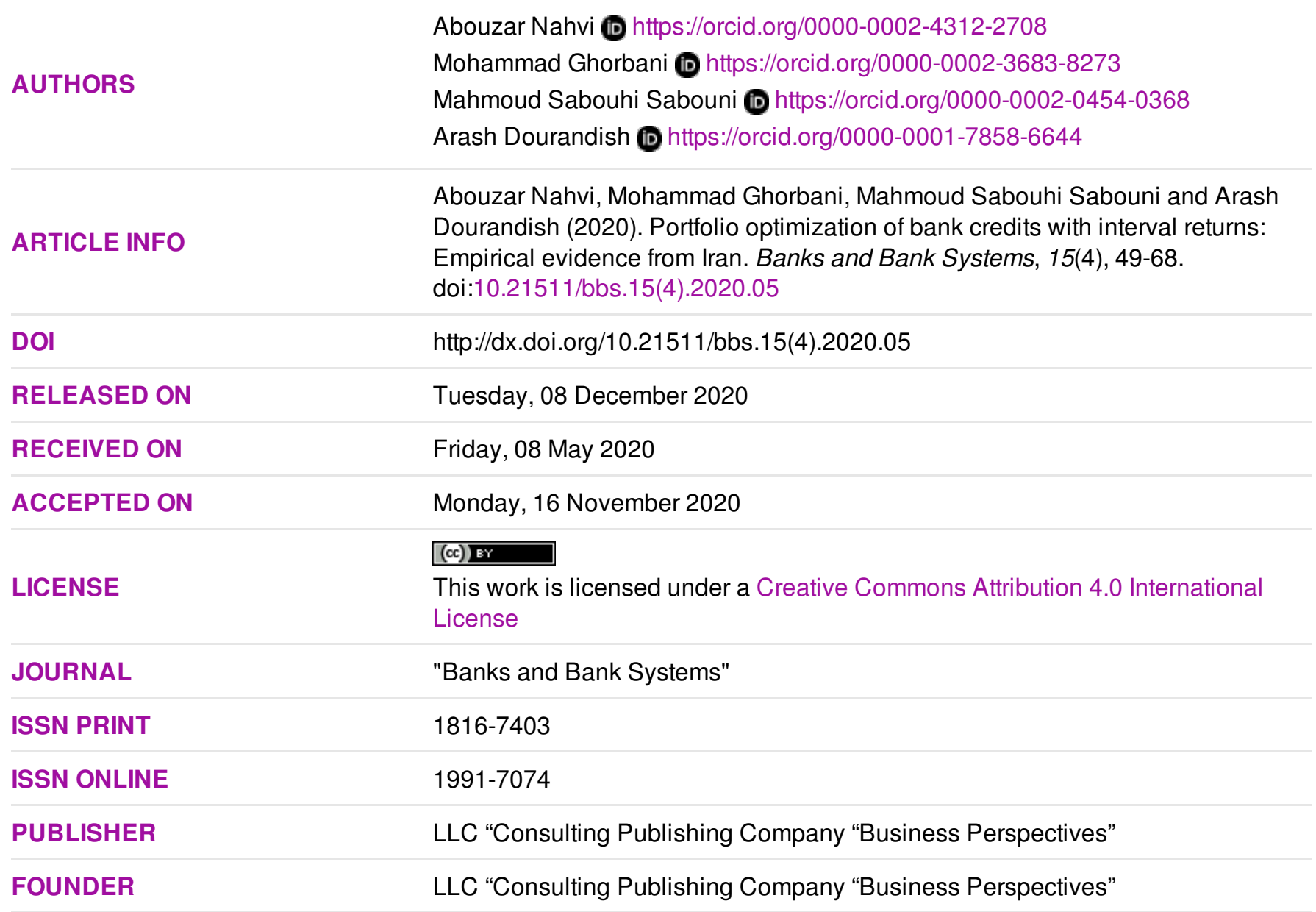

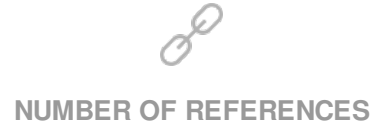

21
NUMBER OF FIGURES

1

\section{E=-}

NUMBER OF TABLES

22

(C) The author(s) 2021. This publication is an open access article. 


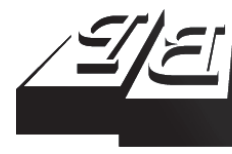

\section{BUSINESS PERSPECTIVES}

LLC "CPC "Business Perspectives" Hryhorii Skovoroda lane, 10, Sumy, 40022, Ukraine www.businessperspectives.org
Abouzar Nahvi (Iran), Mohammad Ghorbani (Iran),

Mahmoud Sabouhi Sabouni (Iran), Arash Dourandish (Iran)

\section{PORTFOLIO OPTIMIZATION OF BANK CREDITS WITH INTERVAL RETURNS: EMPIRICAL EVIDENCE FROM IRAN}

\begin{abstract}
Bank credit is one of the main sources of spending on productivity and economic services. However, because of the limitations in its amount, accurate planning is essential to optimize its allocation to applicants. Despite the total volume of credits allocated to the agricultural sector, as well as the large number of applicants and sub-sectors applying for these facilities, there is still no clear pattern for the optimal allocation of agricultural bank credits in Iran. It is bank managers who must decide on the distribution of financial capital in a competitive environment. Based on this fact, the paper investigates the optimum portfolio composition of the Agricultural Bank credits in accordance with optimistic, pessimistic, and collaborative strategies by using an interval non-linear multi-objective programming model and considering three different states in determining the rate of return using a genetic algorithm. The results showed that the current pattern of the distribution of bank credits is estimated as different from the optimal one. In the optimum patterns estimated in all states, the agriculture, agricultural services, animal husbandry, aviculture and greenhouses sections were assigned the largest shares in their optimum portfolio combination. Managers can choose their desired model according to three studied strategies and depending on the importance, different estimates of return, and risk of each of them.
\end{abstract}

\section{Keywords \\ agricultural sector, interval numbers, genetic algorithm, portfolio selection, risk}

JEL Classification $\quad$ C02, G11, G15

\section{INTRODUCTION}

Arash Dourandish, Ph.D, Associate Professor, Department of Agricultura Economics, Ferdowsi University of Mashhad, Iran.

This is an Open Access article, distributed under the terms of the Creative Commons Attribution 4.0 International license, which permits unrestricted re-use, distribution, and reproduction in any medium, provided the original work is properly cited.

Conflict of interest statement: Author(s) reported no conflict of interest
Granting credits is one of the most common methods for providing capital to productive sectors, such as agriculture businesses. In most countries, governments or financing institutions have a duty to provide credit to agricultural activists. In Iran, the Agricultural Bank is the only specialized bank for the agricultural sector and, thus, plays a major role in meeting the credit needs of agricultural and food producers (Monsef \& Tabatabay, 2013). It should be considered that recipients of credits in the agricultural sector are likely to face more risk and uncertainty than businesses in other sectors, such as industry and social services, due to natural factors and fluctuations in the price of agricultural products. Therefore, they often encounter problems with repaying their installments on time. For this reason, the Agricultural Bank, as the main provider of agricultural credits, is not able to complete payments of its instalments every year (Mohagheghnia \& Shirgholami, 2013).

Attention must be given to the issue of risk and uncertainty in the distribution of bank credits. Risk is a part of banking due to the variety of banking operations, the status of bank capital, and limitations of its 
amount, the status of depositors' resources, and different financial status of each borrower. Risk management in banks is more sensitive and complex than risk management in other sectors of the economy. Risk recognition for each economic sector is of particular importance in the investment process of banks and financial institutions. By realizing the risks of each economic sector, banks can choose a set of economic sections, which ultimately decreases a portfolio's credit risk (Kuwornu et al., 2012; Wu \& Liu, 2012). Nevertheless, changing the structure of a bank's assets seems necessary. Banks must make arrangements by using appropriate portfolios to create conditions that allocate their credits in the best way possible by increasing the demand for loans (Eletter et al., 2010). Different methods can be used to determine optimum portfolios with a minimum risk and maximum returns. Markowitz portfolio theory has created a lot of changes in investor attitudes towards investing and is used as a powerful tool for optimizing portfolio combinations (Lai et al., 2006; Tlig \& Dakhli, 2014). Previous studies have reported the definitive modeling, and the next stage requires risk modeling without considering different economic conditions. Therefore, this study aims to provide a suitable model to help managers and bank officials achieve the best allocation of credits to applicants in different sections by considering economic conditions according to the limitations of the banking system. For this purpose, an interval non-linear multi-objective programming model has been used alongside a genetic meta-heuristic algorithm.

\section{LITERATURE REVIEW}

Given the importance of the selection and optimization of a portfolio, many studies have been performed in this field. For example, Jao (1971) used a linear programming model in an attempt to provide a model for the allocation of credit to Hong Kong's banks. In his study, the objective was to achieve the highest return on investment for Hong Kong's banks by considering constraints and limitations such as limitations of bank credits and legal restrictions. The results indicated that the obtained optimal model was different from the current pattern of banking credit distribution in different parts of the economy of Hong Kong. Chang et al. (2009) investigated portfolio optimization based on different scales for risk measurement and by using a genetic algorithm. Their main goal was to study the efficiency of the genetic algorithm for solving optimizing portfolio with different risk models Their results indicate that smaller portfolios have better performance than large ones. Hao and Liu (2009) used a genetic algorithm for running models they developed based on Markowitz theory. Their results indicated that this model was useful for estimating returns and risks. Aryanezhad et al. (2011) presented a fuzzy randomized multi-objective method for issues related to portfolio selection. The advantage of their model was that the proposed algorithm could be modified to enhance the criteria of other multi-objective decision models. The results of their study showed that the proposed model was comprehensive and practical and could easily be carried out based on the information obtained by the researchers. Agrana et al. (2014) used goal programming to optimize loan portfolio management of a bank in Nigeria. Their results showed that the optimal portfolio differed from the portfolio created using the current model. Khalifa and ZeinEldin (2014) studied the selection of portfolios in the stock market using a fuzzy programming method and investigated issues related to portfolio selection in the stock market. The aim of their research was to find an optimal set of assets for investing in stocks. Therefore, a portfolio selection problem with fuzzy objective function coefficients was investigated. Their study showed that the model had the required performance in model estimation. Roodposhti et al. (2014) aimed to optimize portfolios consisting of stock investment funds by using the genetic algorithm. Their results showed that the genetic algorithm can be used to select a portfolio consisting of the stocks of shared funds and that such portfolios can achieve better performance than those designed using traditional methods. Also, as a portfolio becomes more diverse, the superiority of the performance of the genetic algorithm becomes more significant when using the linear method. Dubinskas and Urbšienè (2017), using a genetic algorithm-based approach and MatLab software, examined the optimal investment portfolio for four selected companies in Lithuania. The results showed that the genetic algorithm-based portfolio reached a better risk-return ratio than the portfolio optimized using the deterministic and stochastic programming 
methods. Metawaa et al. (2017) used a genetic algorithm called Genetic Algorithm Multipopulation Competitive Coevolution (GAMCC) to optimize a bank's financial goals in order to reduce risk and increase facility interest. Their results showed that the proposed model was effective and that its use reduced the facility monitoring time. Gouveia et al. (2018) examined the performance of mutual fund portfolios in Portugal using a value-based DEA method. Their results showed that their proposed method helped investors identify the best ways to make decisions based on their judgments. Lester (2019) investigated a portfolio based on investment theory by comparing a set of single-factor investment portfolios and an integrated portfolio. The results showed that integrated portfolios more accurately predict profits and risk in subsequent investment periods when compared to single-factor investment. Lv et al. (2020) studied the distribution function of the optimal portfolio return based on uncertainty theory. Two types of new uncertain programming models, namely, the chance-mean model and the measure-mean model, are proposed to make an optimal portfolio selection decision in an uncertain environment. It is proved that there is an equivalent relationship between the chancemean model and a deterministic linear programming model, which leads to an approach to obtaining the optimal solutions for the proposed models. Orlova (2020) examined the development of new technologies and models for managing bank lending. The research material was the statistical data from the Bank of Russia. The methods of system analysis, methods of statistics and optimization methods were used. The results showed that the model for optimizing the structure of the loan portfolio was developed, providing a maximum return on the loan portfolio.

\section{METHODOLOGY}

In this study, each of the activities of various recipients of credits was considered as an asset or investment project to determine the optimal portfolio of the studied bank. The data is derived from the Iranian Agricultural Bank Statistics Center from spring 2009 to late March 2014.

Since the main source of expected fluctuations in the banks' revenue is fluctuations in the ratio of collections of granted credits, the amount of collections of credits granted to each of the economic sections was considered as the risk of return and its variance. Typically, the average historical return is considered as the expected return of an asset, which creates a definitive return for each asset. However, its use as a proxy for expected returns has two major weaknesses. First, if historical data is considered over a long time, the returns of recent years are closer to the returns on assets currently. In other words, recent asset data will be more effective than older asset data. Secondly, when the historical data of an asset is not sufficient due to a lack of information, the statistical parameters will not be precise. For these reasons and due to the uncertainty related to the estimates, the expected return on an asset is better considered as an interval value instead of an average value based on historical data. In this study, the expected return range of the asset was determined using financial reports, historical asset information, and expert opinions. At first, the average of the historical return (Ri) for each asset was calculated. Then, the following three states were considered:

1. All rates of return intervals of risky assets are located to the left of the historical mean values of asset returns, which are used as reference points, so that $R i u<R i$ for all $i$. These conditions are shown in Figure 1(a) and represent poor economic conditions (due to pest prevalence, drought, etc.), in which the expected returns of asset types are reduced.

2. All rates of the return intervals of risky assets are selected in such a way that average historical returns of each asset considered as a reference point are placed between them such that $R i \in R A i=[R i l, R i u]$ for all $i$. These conditions are shown in Figure 1(b) and reflect stable economic conditions in which those intervals and the expected returns of all types of assets are included as the average of their historical returns.

3. All rates of the return intervals of risky assets are selected in such a way that average historical returns of each asset (which are considered as reference points) are placed as $R i l>R i$ for all $i$. These conditions are shown in Figure $1(c)$ and represent favorable economic condi- 
(a)

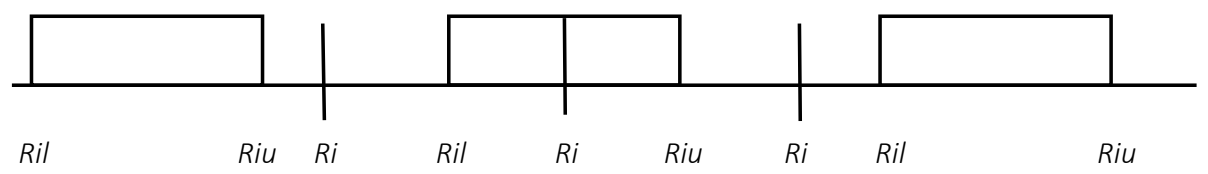

Note: $R i l=$ lower limit of expected returns, $R i u=$ upper limit of expected returns, and $R i=$ mean of historical returns.

Figure 1. Relationship between historical average returns and expected interim returns according to economic conditions

tions. Under these conditions, it is expected that the expected returns for all asset types will increase.

Therefore, the objectives of the optimal portfolio selection are as follows:

$$
\begin{array}{ll}
\text { Minimize } & \tilde{\sigma}^{2}(x) \\
\text { Maximize } & \tilde{R}(x),
\end{array}
$$

The above issue is the interval non-linear multi-objective programming model. A weighted sum method, used to solve multi-objective optimization problems, has been used here to convert the multi-objective model to a one-goal optimization issue as shown below:

$$
\operatorname{Min}\left[\alpha \cdot \tilde{\sigma}^{2}(x)-\beta \cdot \tilde{R}(x)\right]
$$

where $\alpha$ and $\beta$ are the risk and return weights (which can range between 0 and 1). The model can be solved by providing different values to them (between 0 and 1), and the investor can choose a different model based on various estimates of returns and risk.

\subsection{Model limitations}

The most important constraints and limitations of the studied bank regarding its ability to provide credits to customers in the economic sections are as follows: The first limitation is the budget limitations. The bank's budget limitations include the total Rial ${ }^{1}$ volume of facility types that bank allocates to its various economic sections.

$$
\sum_{i=1}^{N} X i \leq B
$$

where $B$ is the volume of the Rial of the credits, which is considered by the bank as being equal to $B$ Rials.
The second limitation is the ratio of facilities to deposits, one of the limitations that can be imposed by the bank's board of directors. A higher ratio is traditionally associated with higher risk since a high ratio indicates lower liquidity, undesirable economic processes, or withdrawal of deposits.

$$
\frac{\sum X i}{\sum C} \leq 80 \%,
$$

where $C$ is total deposits.

The third group of limitations is represented by the legal limitations from the Central Bank. Based on the instructions of the Central Bank, specialized banks were obligated to grant at least $90 \%$ of their facilities for their main mission. As a result, a maximum of $10 \%$ of their total facilities can be offered to firms from areas outside of their expertise to the applicant's departments with the restriction that would be formulated as follows:

$$
\frac{x 10}{\sum B} \leq \% 10
$$

The other group shows the existing limitation for the capital adequacy ratio.

$$
\frac{\text { Equity (Basecapital) }}{\text { Total risk-adjusted assets }} \geq 8 \% \text {. }
$$

The fifth limitation is represented by the minimum and maximum share of each section, which includes minimum and maximum shares of facilities granted to each section.

$$
\begin{aligned}
& X i \leq D, \\
& X i \geq F,
\end{aligned}
$$

where $D$ is the maximum share of each section, and $f$ is the minimum share of each section.

$1 \quad 1$ USD $\approx 218,000$ Rials (August 2020). 


\subsection{Optimal portfolio selection model}

This section presents the portfolio selection model using a numerical example and the data set obtained from Keshavarzi Bank in Iran. The value of the constraints was obtained by placing the data in the formulas of the previous section. Therefore, the multi-objective optimization issue was solved using the weighted method for the following three models.

\section{Model 1. Optimistic strategy}

In this state, the lower limit of risk was minimized minus the upper limit of returns so that the objective function of the model showed that the investor was optimistic about returns and the asset risk.

$$
\operatorname{Min} F l=\alpha \sum_{i=1}^{N} \sum_{j=1}^{N}[\sigma 2 i j l]-\beta \sum_{j=1}^{N}[R i u],
$$

subject to

$$
\sum_{i=1}^{17} X i \leq 189,336,089,818,750 \text {; }
$$

$X 10 \leq 18,933,608,981,875$;

$X i \leq 0.21, X i \geq 0.001$.

\section{Model 2. Pessimistic strategy}

In this state, unlike Model 1 , the upper limit of risk was minimized minus the lower limit of return so that the investor pessimistically estimates returns and the asset risk.

$$
\operatorname{Min} F r=\alpha \sum_{i=1}^{N} \sum_{j=1}^{N}[\sigma 2 i j u]-\beta \sum_{j=1}^{N}[R i l],
$$

subject to

$$
\begin{aligned}
& \sum_{i=1}^{17} X i \leq 189,336,089,818,750 ; \\
& X 10 \leq 18,933,608,981,875 ;
\end{aligned}
$$$$
X i \leq 0.21, X i \geq 0.001 \text {. }
$$

\section{Model 3. Combined strategy}

This model represents a scenario in which the investor chooses his portfolio neither too optimistically nor too pessimistically. The investor tries to balance returns and asset risk. In other words, s/ he is concerned about reducing risk and increasing asset returns.

$$
\operatorname{Min} F(x)=\lambda F r(x)+(1-\lambda) F l(x),
$$

where

$$
\begin{aligned}
& \operatorname{Min} F(x)=\lambda\left[\alpha \sum_{i=1}^{N} \sum_{j=1}^{N}[\sigma 2 i j u]-\right. \\
& -\beta \sum_{j=1}^{N}[R i l]+(1-\lambda)\left[\alpha \sum_{i=1}^{N} \sum_{j=1}^{N}[\sigma 2 i j l]-\right. \\
& -\beta \sum_{j=1}^{N}[R i u]
\end{aligned}
$$

subject to

$\sum_{i=1}^{17} X i \leq 189,336,089,818,750$;

$X 10 \leq 18,933,608,981,875$;

$X i \leq 0.21, \quad X i \geq 0.001$.

where $x i$ is the proportion invested in the asset $i$, $i=1, \cdots, n ; \sigma 2 i j l$ is the lower limit of covariance between the $i$-th and $j$-th assets, and ó $2 i j u$ is the upper limit of covariance between the $i$-th and $j$-th assets; $\alpha$ and $\beta$ are the risk and return weights, and $\lambda$ is a pessimism index, which can range from 0 to 1 . The model can be solved by giving different values (between 0 and 1 ) to these variables. The investor can choose a different model based on various estimates of returns and risk.

There are no effective algorithms in math programming that can be utilized to solve these types of issues. Therefore, this study uses a genetic algorithm to solve the models and determine the optimal portfolio.

\subsection{Genetic algorithm}

The genetic algorithm is a non-linear method that is randomly directed and can find the answer to the problem at hand in this study. It was first presented by John Holland, whose process is as follows:

1. Primary population: In this technique, chromosomes improve frequently during each pe- 
riod, the population changes, and a new generation is created that is stronger than the previous response in terms of its proximity to the optimal answer.

2. Fitness function: At this stage, the proximity of answers to the optimal answer is determined by calculating and assessing the value of the target function for each of the chromosomes.

3. Choice: At this stage, two parents would be selected to mate and produce new chromosomes. In each generation, superior chromosomes should be given a better chance of birth.

4. Performance of the genetic algorithm function: The process of breeding and creating a new generation of answers is done using genetic operators of intersection and mutation.

5. Selection of new generation elements: At this stage, newly created chromosomes are added to the previous population collection. In the following, from the current collection, the best choice will be determined according to the initial population based on fitting function values.

6. Steps 2 to 5 are repeated so that the algorithm gradually achieves optimal response after several generations. Bet on stopping of the issue is also doing a certain number of repetitions, which is determined before the algorithm is applied.

In this work, a solution $X=\left(x_{1}, x_{2}, \ldots, x_{n}\right)$ is encoded by chromosome $C=\left(c_{1}, c_{2}, . ., c_{n}\right)$. The search space of $x_{1}, x_{2} \ldots, x_{n}$ are $[0,1]$. The chromosome that satisfies the constraints of the model is feasible.

A most important reason for using meta-heuristic algorithms is to correctly regulate parameters related to them. Inappropriate regulation of these parameters causes the related algorithm to present more biased results than their potential ability. For this reason, it seems necessary to use efficient methods for parameter regulation. In this study, Taguchi's experimental design method was used to regulate the parameters, and the following parameters of genetic algorithms are considered: population size $=50$, cross over probability $=0.6$, mutation probability $=0.4$, and maximum iteration $=500$.

\section{EMPIRICAL RESULTS AND DISCUSSION}

According to the main purpose of the paper, which is to investigate the optimal portfolio of credits, the amount of facilities paid to each economic sector during the study period, as well as the data and the return values of the three examined states are shown in Tables 1 to 3 in the appendix.

\subsection{Return test normality}

The main assumption for using variance as risk criteria (per the Markowitz method) is based on the normal distribution of returns. The normality of intervals was investigated based on the Kolmogorov-Smirnov test using SPSS.

Table 4. Normality test

\begin{tabular}{c|c|c|c|c} 
State & Mean & $\begin{array}{c}\text { Std. } \\
\text { deviation }\end{array}$ & $\begin{array}{c}\text { Z Kolmogorov- } \\
\text { Smirnov }\end{array}$ & Sig. \\
\hline State 1 & 902 & 36 & 495 & 769 \\
\hline State 2 & 913 & 32 & 529 & 349 \\
\hline State 3 & 937 & 26 & 518 & 259 \\
\hline
\end{tabular}

The results showed that for all studied cases, all obtained $p$-values were greater than 0.05 , which indicates that the distribution of returns is normal in all states.

\subsection{Genetic optimization algorithm performance}

The optimum values that were obtained from the performance of the genetic algorithm are shown in Tables 5 to 22. The proposed algorithm was run using MATLAB 2016. The computational results presented in objective functions 1 and 2 are based on three different sets of values for $\alpha$ and $\beta$, which represent the investor's priority in terms of risk and returns. However, in objective function $3, \alpha$ and $\beta$ were equal to 0.5 for all states, and $\lambda$ was allocated as $0.9,0.5$, and 0.1 . 
Table 5. The contribution of each sector to the objective function 1 of the genetic algorithm in Mode 1

\begin{tabular}{|c|c|c|c|c|c|c|c|c|c|c|c|c|}
\hline \multicolumn{13}{|c|}{ Source: Research finding } \\
\hline Portfolio & $\alpha$ & B & Share of each sector & $x 1$ & $x 2$ & $x 3$ & $x 4$ & $x 5$ & $x 6$ & $x 7$ & $x 8$ & $x 9$ \\
\hline \multirow{5}{*}{ Portfolio 1} & \multirow{5}{*}{0.5} & \multirow{5}{*}{0.5} & Rial & $3,333.968$ & $1,308.664$ & $2,429.248$ & $10,332.923$ & 952.726 & $35,143.639$ & $16,744.354$ & $12,834.382$ & $6,085.739$ \\
\hline & & & Share of each sector (\%) & 1.76 & 0.69 & 1.28 & 5.46 & 0.50 & 18.56 & 8.84 & 6.78 & 3.21 \\
\hline & & & & $x 10$ & $x 11$ & $x 12$ & $x 13$ & $x 14$ & $x 15$ & $x 16$ & $x 17$ & \multirow{3}{*}{-} \\
\hline & & & Rial & $1,710.827$ & $2,734.123$ & $36,445.622$ & $9,549.509$ & $3,005.293$ & $12,975.478$ & $32,487.004$ & $1,262.590$ & \\
\hline & & & Share of each sector (\%) & 0.90 & 1.44 & 19.25 & 5.04 & 1.59 & 6.85 & 17.16 & 0.67 & \\
\hline \multirow{6}{*}{ Portfolio 2} & \multirow{6}{*}{0.25} & \multirow{6}{*}{0.75} & & $x 1$ & $x 2$ & $x 3$ & $x 4$ & $x 5$ & $x 6$ & $x 7$ & $x 8$ & $x 9$ \\
\hline & & & Rial & $2,034.527$ & 867.569 & $3,444.935$ & $7,312.493$ & $2,157.456$ & $32,795.627$ & $23,576.432$ & $6,514.704$ & $5,451.393$ \\
\hline & & & Share of each sector (\%) & 1.07 & 0.46 & 1.82 & 3.86 & 1.14 & 17.32 & 12.45 & 3.44 & 2.88 \\
\hline & & & & $x 10$ & $x 11$ & $x 12$ & $x 13$ & $x 14$ & $x 15$ & $x 16$ & $x 17$ & \multirow{3}{*}{-} \\
\hline & & & Rial & $2,474.889$ & $5,144.191$ & $33,963.029$ & $9,628.635$ & 901.008 & $14,592.435$ & $37,196.803$ & $1,279.963$ & \\
\hline & & & Share of each sector (\%) & 1.31 & 2.72 & 17.94 & 5.09 & 0.48 & 7.71 & 19.65 & 0.68 & \\
\hline \multirow{6}{*}{ Portfolio 3} & \multirow{6}{*}{0.75} & \multirow{6}{*}{0.25} & & $x 1$ & $x 2$ & $x 3$ & $x 4$ & $x 5$ & $x 6$ & $x 7$ & $x 8$ & $x 9$ \\
\hline & & & Rial & $2,025.641$ & $1,674.373$ & $1,052.640$ & $7,027.706$ & 559.587 & $36,296.379$ & $26,152.761$ & $9,409.912$ & $5,872.742$ \\
\hline & & & Share of each sector (\%) & 1.07 & 0.88 & 0.56 & 3.71 & 0.30 & 19.17 & 13.81 & 4.97 & 3.10 \\
\hline & & & & $x 10$ & $x 11$ & $x 12$ & $x 13$ & $x 14$ & $x 15$ & $x 16$ & $x 17$ & \multirow{3}{*}{-} \\
\hline & & & Rial & $4,279.694$ & $1,511.178$ & $36,091.749$ & $8,054.621$ & $2,964.723$ & $11,964.680$ & $32,719.492$ & $1,678.211$ & \\
\hline & & & Share of each sector (\%) & 2.26 & 0.80 & 19.06 & 4.25 & 1.57 & 6.32 & 17.28 & 0.89 & \\
\hline
\end{tabular}

Note: The numbers are in billion Rials (1 USD $\approx 218,000$ Rials (August 2020)).

Table 6. Summary of optimal results in objective function 1 of the genetic algorithm in Mode 1

\begin{tabular}{l|c|c|c|c:c}
\hline Portfolio & $\boldsymbol{\alpha}$ & $\boldsymbol{\beta}$ & Risk & Return & Objective function \\
\hline Portfolio 1 & 0.5 & 0.5 & $4,189,589,070,199,920$ & 88,115 & $4,189,589,070,111,800$ \\
Portfolio 2 & 0.25 & 0.75 & $2,084,228,326,228,330$ & 132,151 & $2,084,228,326,096,180$ \\
\hline Portfolio 3 & 0.75 & 0.25 & $6,123,074,651,070,900$ & 44,103 & $6,123,074,651,026,790$ \\
\hline
\end{tabular}

Note: The numbers are in billion Rials ( 1 USD $\approx 218,000$ Rials (August 2020)). 
Table 7. The contribution of each sector to the objective function 2 of the genetic algorithm in Mode 1

\begin{tabular}{|c|c|c|c|c|c|c|c|c|c|c|c|c|}
\hline Portfolio & $\alpha$ & $\beta$ & Share of each sector & $x 1$ & $x 2$ & $x 3$ & $x 4$ & $x 5$ & $x 6$ & $x 7$ & $x 8$ & $x 9$ \\
\hline \multirow{5}{*}{ Portfolio 1} & \multirow{5}{*}{0.5} & \multirow{5}{*}{0.5} & Rial & $1,680.459$ & $2,049.221$ & $1,441.054$ & $8,783.402$ & $1,876.709$ & $31,375.185$ & $5,659.318$ & $1,649.831$ & $6,378.352$ \\
\hline & & & Share of each sector (\%) & 0.89 & 1.08 & 0.76 & 4.64 & 0.99 & 16.57 & 2.99 & 0.87 & 3.37 \\
\hline & & & & $x 10$ & $x 11$ & $x 12$ & $x 13$ & $x 14$ & $x 15$ & $x 16$ & $x 17$ & \multirow{3}{*}{-} \\
\hline & & & Rial & $1,194.263$ & $1,982.741$ & $37,296.255$ & $8,889.037$ & $5,394.392$ & $34,108.781$ & $37,492.578$ & $2,084.512$ & \\
\hline & & & Share of each sector (\%) & 0.63 & 1.05 & 19.70 & 4.69 & 2.85 & 18.01 & 19.80 & 1.10 & \\
\hline \multirow{6}{*}{ Portfolio 2} & \multirow{6}{*}{0.25} & \multirow{6}{*}{0.75} & & $x 1$ & $x 2$ & $x 3$ & $x 4$ & $x 5$ & $x 6$ & $x 7$ & $x 8$ & $x 9$ \\
\hline & & & Rial & $1,672.294$ & 875.687 & $2,767.718$ & $5,842.145$ & $2,362.535$ & $31,944.003$ & $8,032.749$ & $2,482.523$ & $10,098.286$ \\
\hline & & & Share of each sector (\%) & 0.88 & 0.46 & 1.46 & 3.09 & 1.25 & 16.87 & 4.24 & 1.31 & 5.33 \\
\hline & & & & $x 10$ & $x 11$ & $x 12$ & $x 13$ & $x 14$ & $x 15$ & $x 16$ & $x 17$ & \multirow{3}{*}{-} \\
\hline & & & Rial & $2,097.857$ & $3,032.445$ & $33,868.938$ & $8,104.521$ & $3,178.537$ & $35,934.906$ & $34,812.337$ & $2,228.608$ & \\
\hline & & & Share of each sector (\%) & 1.11 & 1.60 & 17.89 & 4.28 & 1.68 & 18.98 & 18.39 & 1.18 & \\
\hline \multirow{6}{*}{ Portfolio 3} & \multirow{6}{*}{0.75} & \multirow{6}{*}{0.25} & & $x 1$ & $x 2$ & $x 3$ & $x 4$ & $x 5$ & $x 6$ & $x 7$ & $x 8$ & $x 9$ \\
\hline & & & Rial & $2,429.924$ & $1,686.185$ & $1,226.481$ & $10,292.852$ & 927.286 & $30,257.284$ & $4,782.478$ & $1,941.934$ & $9,369.098$ \\
\hline & & & Share of each sector (\%) & 1.28 & 0.89 & 0.65 & 5.44 & 0.49 & 15.98 & 2.53 & 1.03 & 4.95 \\
\hline & & & & $x 10$ & $x 11$ & $x 12$ & $x 13$ & $x 14$ & $x 15$ & $x 16$ & $x 17$ & \multirow{3}{*}{-} \\
\hline & & & Rial & $3,489.316$ & $1,693.711$ & $35,312.929$ & $9,351.103$ & $3,016.436$ & $36,344.877$ & $35,346.311$ & $1,867.884$ & \\
\hline & & & Share of each sector (\%) & 1.84 & 0.89 & 18.65 & 4.94 & 1.59 & 19.20 & 18.67 & 0.99 & \\
\hline
\end{tabular}

Note: The numbers are in billion Rials ( 1 USD $\approx 218,000$ Rials (August 2020)).

Table 8. Summary of optimal portfolio results in objective function 2 of the genetic algorithm in Mode 1

\begin{tabular}{l|c|c|c|c|c}
\hline \multicolumn{1}{c|}{ Portfolio } & $\boldsymbol{\alpha}$ & $\boldsymbol{\beta}$ & Risk & Return & Objective function \\
\hline Portfolio 1 & 0.5 & 0.5 & $329,904,516,344,610$ & 86,478 & $329,904,516,258,132$ \\
\hdashline Portfolio 2 & 0.25 & 0.75 & $172,558,889,929,985$ & 129,580 & $172,558,889,800,405$ \\
Portfolio 3 & 0.75 & 0.25 & $499,371,233,742,902$ & 43,186 & $499,371,233,699,716$ \\
\hline
\end{tabular}

Note: The numbers are in billion Rials ( 1 USD $\approx 218,000$ Rials (August 2020)). 
Table 9. The contribution of each sector to the objective function 3 of the genetic algorithm in Mode 1

\begin{tabular}{|c|c|c|c|c|c|c|c|c|c|c|c|c|c|}
\hline & & & & & & & & & & & & Source & search findin \\
\hline Portfolio & $\alpha$ & $\beta$ & $\lambda$ & Share of each sector & $x 1$ & $x 2$ & $x 3$ & $x 4$ & $x 5$ & $x 6$ & $x 7$ & $x 8$ & $x 9$ \\
\hline \multirow{5}{*}{ Portfolio 1} & \multirow{5}{*}{0.5} & \multirow{5}{*}{0.5} & \multirow{5}{*}{0.1} & Rial & $1,420.541$ & 194.935 & $3,283.735$ & $4,885.528$ & $1,075.483$ & $34,938.841$ & $28,876.447$ & $8,274.878$ & $4,700.782$ \\
\hline & & & & Share of each sector (\%) & 0.75 & 0.10 & 1.73 & 2.58 & 0.57 & 18.45 & 15.25 & 4.37 & 2.48 \\
\hline & & & & & $x 10$ & $x 11$ & $x 12$ & $x 13$ & $x 14$ & $x 15$ & $x 16$ & $x 17$ & \multirow{3}{*}{-} \\
\hline & & & & Rial & $3,160.119$ & $5,230.869$ & $34,732.783$ & $10,711.539$ & $2,566.397$ & $9,337.176$ & $34,662.185$ & $1,283.851$ & \\
\hline & & & & Share of each sector (\%) & 1.67 & 2.76 & 18.34 & 5.66 & 1.36 & 4.93 & 18.31 & 0.68 & \\
\hline \multirow{6}{*}{ Portfolio 2} & \multirow{6}{*}{0.5} & \multirow{6}{*}{0.5} & \multirow{6}{*}{0.5} & & $x 1$ & $x 2$ & $x 3$ & $x 4$ & $x 5$ & $x 6$ & $x 7$ & $x 8$ & $x 9$ \\
\hline & & & & Rial & 790.643 & $1,617.053$ & $4,057.628$ & $4,633.912$ & $1,157.228$ & $36,237.496$ & $13,373.292$ & $13,630.359$ & $4,537.034$ \\
\hline & & & & Share of each sector (\%) & 0.42 & 0.85 & 2.14 & 2.45 & 0.61 & 19.14 & 7.06 & 7.20 & 2.40 \\
\hline & & & & & $x 10$ & $x 11$ & $x 12$ & $x 13$ & $x 14$ & $x 15$ & $x 16$ & $x 17$ & \multirow{3}{*}{-} \\
\hline & & & & Rial & $1,103.606$ & $3,408.701$ & $35,200.947$ & $12,198.321$ & $1,616.802$ & $19,964.999$ & $34,527.617$ & $1,280.451$ & \\
\hline & & & & Share of each sector (\%) & 0.58 & 1.80 & 18.59 & 6.44 & 0.85 & 10.54 & 18.24 & 0.68 & \\
\hline \multirow{6}{*}{ Portfolio 3} & \multirow{6}{*}{0.5} & \multirow{6}{*}{0.5} & \multirow{6}{*}{0.9} & & $x 1$ & $x 2$ & $x 3$ & $x 4$ & $x 5$ & $x 6$ & $x 7$ & $x 8$ & $x 9$ \\
\hline & & & & Rial & 989.076 & $1,422.136$ & $4,000.755$ & $8,444.389$ & $1,067.596$ & $32,398.406$ & $5,936.871$ & $6,220.586$ & $7,425.875$ \\
\hline & & & & Share of each sector (\%) & 0.52 & 0.75 & 2.11 & 4.46 & 0.56 & 17.11 & 3.14 & 3.29 & 3.92 \\
\hline & & & & & $x 10$ & $x 11$ & $x 12$ & $x 13$ & $x 14$ & $x 15$ & $x 16$ & $x 17$ & \multirow{3}{*}{-} \\
\hline & & & & Rial & $2,544.228$ & $2,826.942$ & $35,869.612$ & $8,746.624$ & $1,963.787$ & $3,3691.337$ & $34,844.512$ & 943.357 & \\
\hline & & & & Share of each sector (\%) & 1.34 & 1.49 & 18.94 & 4.62 & 1.04 & 17.79 & 18.40 & 0.50 & \\
\hline
\end{tabular}

Note: The numbers are in billion Rials (1 USD $\approx 218,000$ Rials (August 2020)).

Table 10. Summary of optimal portfolio results in objective function 3 of the genetic algorithm in Mode 1

\begin{tabular}{l|c|c|c:c|c|c}
\hline Portfolio & $\boldsymbol{\alpha}$ & $\boldsymbol{\beta}$ & $\boldsymbol{\lambda}$ & Risk & Return & Objective function \\
\hline Portfolio 1 & 0.5 & 0.5 & 0.1 & {$[3,993,902,282,746,190 ; 737,139,973,640,715]$} & {$[87,280 ; 88,269]$} & $3,646,216,692,376,570$ \\
\hdashline Portfolio 2 & 0.5 & 0.5 & 0.5 & {$[413,694,481,838,116 ; 4,017,814,802,003,130]$} & {$[87,135 ; 88,155]$} & $089,238,146,457,512,2$ \\
\hdashline Portfolio 3 & 0.5 & 0.5 & 0.9 & {$[422,339,892,073,433 ; 362,927,021,337,243]$} & {$[86,612 ; 87,703]$} & $730,799,700,651,818$ \\
\hline
\end{tabular}

Note: The numbers are in billion Rials (1 USD $\approx 218,000$ Rials (August 2020)). 


\begin{tabular}{|c|c|c|c|c|c|c|c|c|c|c|c|c|}
\hline \multicolumn{13}{|c|}{ Source: Research findings } \\
\hline Portfolio & $\alpha$ & $\beta$ & Share of each sector & $X 1$ & $x 2$ & $x 3$ & $X 4$ & $\times 5$ & $x_{6}$ & $x 7$ & $x 8$ & $x 9$ \\
\hline \multirow{5}{*}{ Portfolio1 } & \multirow{5}{*}{0.5} & \multirow{5}{*}{0.5} & Rial & $3,205.325$ & $1,648.734$ & $1,439.798$ & $13,162.943$ & $1,137.743$ & $34,792.124$ & $6,458.196$ & $8,644.964$ & $5,908.145$ \\
\hline & & & Share of each sector (\%) & 1.69 & 0.87 & 0.76 & 6.95 & 0.60 & 18.38 & 3.41 & 4.57 & 3.12 \\
\hline & & & & $x 10$ & $x 11$ & $x 12$ & $x 13$ & $x 14$ & $x 15$ & $x 16$ & $x 17$ & \multirow{3}{*}{-} \\
\hline & & & Rial & $2,294.631$ & $3,046.618$ & $37,362.143$ & $11,933.717$ & $2,059.622$ & $22,259.441$ & $32,885.312$ & $1,096.633$ & \\
\hline & & & Share of each sector (\%) & 1.21 & 1.61 & 19.73 & 6.30 & 1.09 & 11.76 & 17.37 & 0.58 & \\
\hline \multirow{6}{*}{ Portfolio2 } & \multirow{6}{*}{0.25} & \multirow{6}{*}{0.75} & & $x 1$ & $x 2$ & $x 3$ & X4 & $x 5$ & $x 6$ & $x 7$ & $x 8$ & $x 9$ \\
\hline & & & Rial & $2,444.844$ & 504.343 & $2,523.073$ & $10,599.531$ & $2,600.387$ & $39,506.811$ & $11,466.696$ & $9,654.597$ & $2,175.947$ \\
\hline & & & Share of each sector (\%) & 1.29 & 0.27 & 1.33 & 5.60 & 1.37 & 20.87 & 6.06 & 5.10 & 1.15 \\
\hline & & & & $x 10$ & $x 11$ & $x 12$ & $x 13$ & $x 14$ & $x 15$ & $x 16$ & $x 17$ & \multirow{3}{*}{-} \\
\hline & & & Rial & $2,248.667$ & $2,531.583$ & $34,293.848$ & $6,554.624$ & $2,296.434$ & $20,716.807$ & $37,511.486$ & $1,706.411$ & \\
\hline & & & Share of each sector (\%) & 1.19 & 1.34 & 18.11 & 3.46 & 1.21 & 10.94 & 19.81 & 0.90 & \\
\hline \multirow{6}{*}{ Portfolio3 } & \multirow{6}{*}{0.75} & \multirow{6}{*}{0.25} & & $x 1$ & $x 2$ & $x 3$ & $x 4$ & $x 5$ & $x 6$ & $x 7$ & $x 8$ & $x 9$ \\
\hline & & & Rial & $2,165.935$ & $1,666.026$ & $1,410.983$ & $8,214.343$ & 741.718 & $36,177.228$ & $13,386.306$ & $7,785.513$ & $8,340.171$ \\
\hline & & & Share of each sector (\%) & 1.14 & 0.88 & 0.75 & 4.34 & 0.39 & 19.11 & 7.07 & 4.11 & 4.40 \\
\hline & & & & $x 10$ & $x 11$ & $x 12$ & $x 13$ & $x 14$ & $x 15$ & $x 16$ & $x 17$ & \multirow{3}{*}{-} \\
\hline & & & Rial & $4,841.129$ & 955.359 & $36,655.503$ & $7,019.324$ & $1,910.798$ & $21,001.467$ & $35,415.011$ & $1,649.275$ & \\
\hline & & & Share of each sector (\%) & 2.56 & 0.50 & 19.36 & 3.71 & 1.01 & 11.09 & 18.70 & 0.87 & \\
\hline
\end{tabular}

Note: The numbers are in billion Rials ( 1 USD $\approx 218,000$ Rials (August 2020)).

Table 12. Summary of optimal portfolio results in objective function 1 of the genetic algorithm in Mode 2

\begin{tabular}{l|c|c|c|c|c}
\hline \multicolumn{1}{c|}{ Portfolio } & $\boldsymbol{\alpha}$ & $\boldsymbol{\beta}$ & Risk & Return & Objective function \\
\hline Portfolio 1 & 0.5 & 0.5 & $2,143,245,632,778,060$ & 88,700 & $2,143,245,632,689,360$ \\
\hdashline Portfolio 2 & 0.25 & 0.75 & $1,058,730,563,764,430$ & 133,183 & $1,058,730,563,631,250$ \\
\hdashline Portfolio 3 & 0.75 & 0.25 & $3,138,913,168,729,130$ & 44,400 & $3,138,913,168,684,730$ \\
\hline
\end{tabular}

Note: The numbers are in billion Rials ( 1 USD $\approx 218,000$ Rials (August 2020)). 
Table 13. The contribution of each sector to the objective function 2 of the genetic algorithm in Mode 2

\begin{tabular}{|c|c|c|c|c|c|c|c|c|c|c|c|c|}
\hline \multirow{2}{*}{ Portfolio } & \multirow[b]{2}{*}{$\alpha$} & \multirow[b]{2}{*}{$\beta$} & \multirow[b]{2}{*}{ Share of each sector } & \multirow[b]{2}{*}{$X 1$} & \multirow[b]{2}{*}{$x 2$} & \multirow[b]{2}{*}{$X 3$} & \multirow[b]{2}{*}{$X 4$} & \multirow[b]{2}{*}{$X 5$} & \multirow[b]{2}{*}{$x 6$} & \multirow[b]{2}{*}{$x 7$} & \multicolumn{2}{|c|}{ Source: Research finding } \\
\hline & & & & & & & & & & & $x 8$ & $\times 9$ \\
\hline \multirow{5}{*}{ Portfolio1 } & \multirow{5}{*}{0.5} & \multirow{5}{*}{0.5} & Rial & $1,448.741$ & $2,137.747$ & $2,957.142$ & $5,394.458$ & $2,579.934$ & $6,548.985$ & $7,457.013$ & $28,295.103$ & $2,023.233$ \\
\hline & & & Share of each sector (\%) & 0.77 & 1.13 & 1.56 & 2.85 & 1.36 & 3.46 & 3.94 & 14.94 & 1.07 \\
\hline & & & & $x 10$ & $x 11$ & $x 12$ & $x 13$ & $x 14$ & $x 15$ & $x 16$ & $x 17$ & \multirow{3}{*}{-} \\
\hline & & & Rial & $1,650.155$ & $2,888.191$ & $36,447.485$ & $12,690.352$ & $1,995.936$ & $39,760.578$ & $32,897.385$ & $2,163.651$ & \\
\hline & & & Share of each sector (\%) & 0.87 & 1.53 & 19.25 & 6.70 & 1.05 & 21 & 17.38 & 1.14 & \\
\hline \multirow{6}{*}{ Portfolio2 } & \multirow{6}{*}{0.25} & \multirow{6}{*}{0.75} & & $x 1$ & $x 2$ & $x 3$ & $x 4$ & $x 5$ & $x 6$ & $x 7$ & $x 8$ & $x 9$ \\
\hline & & & Rial & $1,492.932$ & 194.948 & $3,277.022$ & $3,084.831$ & $1,062.959$ & $5,882.113$ & 10,993.971 & $37,317.803$ & 4373.431 \\
\hline & & & Share of each sector (\%) & 0.79 & 0.10 & 1.73 & 1.63 & 0.56 & 3.11 & 5.81 & 19.71 & 2.31 \\
\hline & & & & $x 10$ & $x 11$ & $x 12$ & $x 13$ & $x 14$ & $x 15$ & $x 16$ & $x 17$ & \multirow{3}{*}{-} \\
\hline & & & Rial & $2,631.885$ & $2,398.051$ & $31,972.873$ & $13,168.751$ & $2,932.047$ & $34,282.496$ & $32,969.187$ & $1,300.789$ & \\
\hline & & & Share of each sector (\%) & 1.39 & 1.27 & 16.89 & 6.96 & 1.55 & 18.11 & 17.41 & 0.69 & \\
\hline \multirow{6}{*}{ Portfolio3 } & \multirow{6}{*}{0.75} & \multirow{6}{*}{0.25} & & $x 1$ & $x 2$ & $x 3$ & $x 4$ & $x 5$ & $x 6$ & $x 7$ & $x 8$ & $x 9$ \\
\hline & & & Rial & 976.819 & $2,324.431$ & $3,347.238$ & $3,704.171$ & $2,285.671$ & $7,637.997$ & $10,466.899$ & $32,805.351$ & 4408.077 \\
\hline & & & Share of each sector (\%) & 0.52 & 1.23 & 1.77 & 1.96 & 1.21 & 4.03 & 5.53 & 17.33 & 2.33 \\
\hline & & & & $x 10$ & $x 11$ & $x 12$ & $x 13$ & $x 14$ & $x 15$ & $x 16$ & $x 17$ & \multirow{3}{*}{-} \\
\hline & & & Rial & $1,279.165$ & $1,208.473$ & $35,491.763$ & $12,094.507$ & $1,783.883$ & $34,421.739$ & $33,309.922$ & $1,789.983$ & \\
\hline & & & Share of each sector (\%) & 0.68 & 0.64 & 18.75 & 6.39 & 0.94 & 18.18 & 17.59 & 0.95 & \\
\hline
\end{tabular}

Note: The numbers are in billion Rials ( 1 USD $\approx 218,000$ Rials (August 2020))

Table 14. Summary of optimal results in objective function 2 of the genetic algorithm in Mode 2

\begin{tabular}{l|c|c|c|c|c}
\hline \multicolumn{1}{c|}{ Portfolio } & $\boldsymbol{\alpha}$ & $\boldsymbol{\beta}$ & Risk & Return & Objective function \\
\hline Portfolio 1 & 0.5 & 0.5 & $543,624,312,718,251$ & 87,631 & $543,624,312,630,619$ \\
Portfolio 2 & 0.25 & 0.75 & $246,135,362,907,107$ & 131,934 & $246,135,362,775,172$ \\
Portfolio 3 & 0.75 & 0.25 & $767,852,601,070,383$ & 43,943 & $767,852,601,026,440$ \\
\hline
\end{tabular}

Note: The numbers are in billion Rials ( 1 USD $\approx 218,000$ Rials (August 2020)). 


\begin{tabular}{|c|c|c|c|c|c|c|c|c|c|c|c|c|c|}
\hline \multirow{2}{*}{ Portfolio } & \multirow[b]{2}{*}{$\alpha$} & \multirow[b]{2}{*}{$\beta$} & \multirow[b]{2}{*}{$\lambda$} & \multirow[b]{2}{*}{ Share of each sector } & \multirow[b]{2}{*}{$X 1$} & \multirow[b]{2}{*}{$x 2$} & \multirow[b]{2}{*}{$x 3$} & \multirow[b]{2}{*}{$X 4$} & \multirow[b]{2}{*}{$x 5$} & \multirow[b]{2}{*}{$x 6$} & \multicolumn{3}{|c|}{ Source: Research findings } \\
\hline & & & & & & & & & & & $x 7$ & $x 8$ & $\times 9$ \\
\hline \multirow{5}{*}{ Portfolio 1} & \multirow{5}{*}{0.5} & \multirow{5}{*}{0.5} & \multirow{5}{*}{0.1} & Rial & $1,822.948$ & $2,744.318$ & $4,312.077$ & $9,274.044$ & $2,515.326$ & $37,817.304$ & $11,695.564$ & $6,914.302$ & 4,913.004 \\
\hline & & & & Share of each sector (\%) & 0.96 & 1.45 & 2.28 & 4.90 & 1.33 & 19.97 & 6.18 & 3.65 & 2.59 \\
\hline & & & & & $x 10$ & $x 11$ & $x 12$ & $x 13$ & $x 14$ & $x 15$ & $x 16$ & $x 17$ & \multirow{3}{*}{-} \\
\hline & & & & Rial & $2,683.426$ & $2,357.955$ & $36,276.934$ & $7,465.192$ & $1,697.164$ & $21,509.743$ & $34,393.551$ & 943.237 & \\
\hline & & & & Share of each sector (\%) & 1.42 & 1.25 & 19.16 & 3.94 & 0.90 & 11.36 & 18.17 & 0.50 & \\
\hline \multirow{6}{*}{ Portfolio 2} & \multirow{6}{*}{0.5} & \multirow{6}{*}{0.5} & \multirow{6}{*}{0.5} & & $x 1$ & $x 2$ & $x 3$ & $x 4$ & $x 5$ & $x 6$ & $x 7$ & $x 8$ & $x 9$ \\
\hline & & & & Rial & $1,606.483$ & 877.427 & $2,001.025$ & $6,414.177$ & 674.453 & $36,883.793$ & $10,966.593$ & $11,757.901$ & $7,325.224$ \\
\hline & & & & Share of each sector (\%) & 0.85 & 0.46 & 1.06 & 3.39 & 0.36 & 19.48 & 5.79 & 6.21 & 3.87 \\
\hline & & & & & $x 10$ & $x 11$ & $x 12$ & $x 13$ & $x 14$ & $x 15$ & $x 16$ & $x 17$ & \multirow{3}{*}{-} \\
\hline & & & & Rial & $1,525.018$ & $3,343.789$ & $37,228.451$ & $12,892.699$ & $1,553.682$ & $21,317.136$ & $30,449.237$ & $2,519.001$ & \\
\hline & & & & Share of each sector (\%) & 0.81 & 1.77 & 19.66 & 6.81 & 0.82 & 11.26 & 16.08 & 1.33 & \\
\hline \multirow{6}{*}{ Portfolio 3} & \multirow{6}{*}{0.5} & \multirow{6}{*}{0.5} & \multirow{6}{*}{0.9} & & $x 1$ & $x 2$ & x3 & $x 4$ & $x 5$ & $x 6$ & $x 7$ & $x 8$ & $x 9$ \\
\hline & & & & Rial & $2,032.581$ & $2,044.034$ & $2,064.199$ & $4,304.587$ & $1,072.175$ & $14,297.381$ & $12,115.303$ & $26,836.251$ & $4,609.153$ \\
\hline & & & & Share of each sector (\%) & 1.07 & 1.08 & 1.09 & 2.27 & 0.57 & 7.55 & 6.40 & 14.17 & 2.43 \\
\hline & & & & & $x 10$ & $x 11$ & $x 12$ & $x 13$ & $x 14$ & $x 15$ & $x 16$ & $x 17$ & \multirow{3}{*}{-} \\
\hline & & & & Rial & $3,093.109$ & $1,525.388$ & $3,3813.956$ & $9,049.241$ & $4,446.883$ & $32,655.613$ & $34,807.522$ & 568.713 & \\
\hline & & & & Share of each sector (\%) & 1.63 & 0.81 & 17.86 & 4.78 & 2.35 & 17.25 & 18.38 & 0.30 & \\
\hline
\end{tabular}

Note: The numbers are in billion Rials (1 USD $\approx 218,000$ Rials (August 2020)).

Table16. Summary of optimal portfolio results in objective function 3 of the genetic algorithm in Mode 2

\begin{tabular}{c|c|c|c|c|c:c}
\hline Portfolio & $\boldsymbol{\alpha}$ & $\boldsymbol{\beta}$ & $\boldsymbol{\lambda}$ & Risk & Return & Objective function \\
\hline Portfolio 1 & 0.5 & 0.5 & 0.1 & {$[806,316,890,611,963 ; 2,231,742,082,491,150]$} & {$[87,156 ; 88,728]$} & $2,089,199,563,214,660$ \\
Portfolio 2 & 0.5 & 0.5 & 0.5 & {$[702,766,441,401,162 ; 2,092,772,920,414,530]$} & {$[87,368 ; 88,887]$} & $1,397,769,680,819,720$ \\
Portfolio 3 & 0.5 & 0.5 & 0.9 & {$[559,359,954,521,887 ; 251,557,690,599,799]$} & {$[87,666 ; 89,242]$} & $754,981,649,590,597$ \\
\hline
\end{tabular}

Note: The numbers are in billion Rials ( 1 USD $\approx 218,000$ Rials (August 2020)). 
Table 17. The contribution of each sector to the objective function 1 of the genetic algorithm in Mode 3

\begin{tabular}{|c|c|c|c|c|c|c|c|c|c|c|c|c|}
\hline & & & & & & & & & & & Source: & search findin \\
\hline Portfolio & $\alpha$ & $\beta$ & Share of each sector & $X 1$ & $x 2$ & $x 3$ & X4 & $\times 5$ & $x 6$ & $x 7$ & $x 8$ & $\times 9$ \\
\hline \multirow{5}{*}{ Portfolio 1} & \multirow{5}{*}{0.5} & \multirow{5}{*}{0.5} & Rial & $1,895.283$ & $1,944.805$ & $2,256.364$ & $4,372.499$ & $2,159.549$ & $3,844.073$ & $23,390.122$ & $28,898.883$ & $3,494.482$ \\
\hline & & & Share of each sector (\%) & 1 & 1.03 & 1.19 & 2.31 & 1.14 & 2.03 & 12.35 & 15.26 & 1.85 \\
\hline & & & & $x 10$ & $x 11$ & $x 12$ & $x 13$ & $x 14$ & $x 15$ & $x 16$ & $x 17$ & \multirow{3}{*}{-} \\
\hline & & & Rial & $1,851.647$ & $1,346.222$ & $35,692.272$ & $8,701.121$ & $2,351.716$ & $30,103.491$ & $35,939.533$ & $1,094.027$ & \\
\hline & & & Share of each sector (\%) & 0.98 & 0.71 & 18.85 & 4.60 & 1.24 & 15.90 & 18.98 & 0.58 & \\
\hline \multirow{6}{*}{ Portfolio 2} & \multirow{6}{*}{0.25} & \multirow{6}{*}{0.75} & & $x 1$ & $x 2$ & $x 3$ & $x 4$ & $x 5$ & $x 6$ & $x 7$ & $x 8$ & $x 9$ \\
\hline & & & Rial & $1,640.732$ & 675.934 & $3,316.759$ & $2,962.346$ & $2,859.522$ & $3,828.888$ & $21,700.916$ & $23,564.845$ & $3,227.559$ \\
\hline & & & Share of each sector (\%) & 0.87 & 0.36 & 1.75 & 1.56 & 1.51 & 2.02 & 11.46 & 12.45 & 1.70 \\
\hline & & & & $x 10$ & $x 11$ & $x 12$ & $x 13$ & $x 14$ & $x 15$ & $x 16$ & $x 17$ & \multirow{3}{*}{-} \\
\hline & & & Rial & $1,401.401$ & $3,178.271$ & $35,469.948$ & $12,664.102$ & $3,324.279$ & $34,854.582$ & $33,320.129$ & $1,345.876$ & \\
\hline & & & Share of each sector (\%) & 0.74 & 1.68 & 18.73 & 6.69 & 1.76 & 18.41 & 17.60 & 0.71 & \\
\hline \multirow{6}{*}{ Portfolio 3} & \multirow{6}{*}{0.75} & \multirow{6}{*}{0.25} & & $x 1$ & $x 2$ & $x 3$ & $x 4$ & $x 5$ & $x 6$ & $x 7$ & $x 8$ & $x 9$ \\
\hline & & & Rial & $3,945.597$ & $1,497.928$ & $1,044.791$ & $4,370.451$ & $1,121.608$ & $5,956.378$ & $25,207.057$ & $23,078.864$ & $4,022.178$ \\
\hline & & & Share of each sector (\%) & 2.08 & 0.79 & 0.55 & 2.31 & 0.59 & 3.15 & 13.31 & 12.19 & 2.12 \\
\hline & & & & $x 10$ & $x 11$ & $x 12$ & $x 13$ & $x 14$ & $x 15$ & $x 16$ & $x 17$ & \multirow{3}{*}{-} \\
\hline & & & Rial & $3,119.245$ & 780.994 & $37,920.787$ & $6,856.839$ & $3,543.815$ & $31,749.712$ & $33,971.618$ & $1,148.227$ & \\
\hline & & & Share of each sector (\%) & 1.65 & 0.41 & 20.03 & 3.62 & 1.87 & 16.77 & 17.94 & 0.61 & \\
\hline
\end{tabular}

Note: The numbers are in billion Rials ( 1 USD $\approx 218,000$ Rials (August 2020))

Table 18. Summary of optimal results in objective function 1 of the genetic algorithm in Mode 3

\begin{tabular}{|c|c|c|c|c|c|}
\hline Portfolio & $\alpha$ & $\beta$ & Risk & Return & Objective function \\
\hline Portfolio 1 & 0.5 & 0.5 & $935,675,627,828,503$ & 90,509 & $935,675,627,737,994$ \\
\hline Portfolio 2 & 0.25 & 0.75 & $478,166,742,067,320$ & 135,429 & $478,166,741,931,891$ \\
\hline Portfolio 3 & 0.75 & 0.25 & $1,476,328,672,376,590$ & 45,156 & $1,476,328,672,331,440$ \\
\hline
\end{tabular}

Note: The numbers are in billion Rials (1 USD $\approx 218,000$ Rials (August 2020)). 


\begin{tabular}{|c|c|c|c|c|c|c|c|c|c|c|c|c|}
\hline \multirow{2}{*}{ Portfolio } & \multirow[b]{2}{*}{$\alpha$} & \multirow[b]{2}{*}{$\beta$} & \multirow[b]{2}{*}{ Share of each sector } & \multirow[b]{2}{*}{$X 1$} & \multirow[b]{2}{*}{$x 2$} & \multirow[b]{2}{*}{$x 3$} & \multirow[b]{2}{*}{$X 4$} & \multirow[b]{2}{*}{$x 5$} & \multirow[b]{2}{*}{$x_{6}$} & \multirow[b]{2}{*}{$x 7$} & \multicolumn{2}{|c|}{ Source: Research finding } \\
\hline & & & & & & & & & & & $x 8$ & $x 9$ \\
\hline \multirow{5}{*}{ Portfolio 1} & \multirow{5}{*}{0.5} & \multirow{5}{*}{0.5} & Rial & $1,534.083$ & $2,508.978$ & $2,634.413$ & $3,062.785$ & $2,607.571$ & $8,082.911$ & $25,546.312$ & $35,780.727$ & $3,464.278$ \\
\hline & & & Share of each sector (\%) & 0.81 & 1.33 & 1.39 & 1.62 & 1.38 & 4.27 & 13.49 & 18.90 & 1.83 \\
\hline & & & & $x 10$ & $x 11$ & $x 12$ & $x 13$ & $x 14$ & $x 15$ & $x 16$ & $x 17$ & \multirow{3}{*}{-} \\
\hline & & & Rial & 979.716 & $2,449.341$ & $30,733.258$ & $5,707.728$ & $2,742.388$ & $26,815.882$ & $33,173.782$ & $1,511.936$ & \\
\hline & & & Share of each sector (\%) & 0.52 & 1.29 & 16.23 & 3.01 & 1.45 & 14.16 & 17.52 & 0.80 & \\
\hline \multirow{6}{*}{ Portfolio 2} & \multirow{6}{*}{0.25} & \multirow{6}{*}{0.75} & & $x 1$ & $x 2$ & $x 3$ & $x 4$ & $x 5$ & $x 6$ & $x 7$ & $x 8$ & $x 9$ \\
\hline & & & Rial & $1,687.689$ & 386.418 & $2,495.339$ & $3,517.181$ & 919.246 & $6,003.195$ & $24,912.236$ & $34,999.425$ & $7,462.623$ \\
\hline & & & Share of each sector (\%) & 0.89 & 0.20 & 1.32 & 1.86 & 0.49 & 3.17 & 13.16 & 18.49 & 3.94 \\
\hline & & & & $x 10$ & $x 11$ & $x 12$ & $x 13$ & $x 14$ & $x 15$ & $x 16$ & $x 17$ & \multirow{3}{*}{-} \\
\hline & & & Rial & $2,140.912$ & $2,454.759$ & $36,366.157$ & $12,421.907$ & $2,667.596$ & $16,579.281$ & $32,862.327$ & $1,459.798$ & \\
\hline & & & Share of each sector (\%) & 1.13 & 1.30 & 19.21 & 6.56 & 1.41 & 8.76 & 17.36 & 0.77 & \\
\hline \multirow{6}{*}{ Portfolio 3} & \multirow{6}{*}{0.75} & \multirow{6}{*}{0.25} & & $x 1$ & $x 2$ & $x 3$ & $x 4$ & $x 5$ & $x 6$ & $x 7$ & $x 8$ & $x 9$ \\
\hline & & & Rial & 945.097 & $2,257.153$ & $3,632.191$ & $3,521.995$ & $1,747.801$ & $6,943.211$ & $31,321.169$ & $31,233.241$ & $2,965.594$ \\
\hline & & & Share of each sector (\%) & 0.50 & 1.19 & 1.92 & 1.86 & 0.92 & 3.67 & 16.54 & 16.50 & 1.57 \\
\hline & & & & $x 10$ & $x 11$ & $x 12$ & $x 13$ & $x 14$ & $x 15$ & $x 16$ & $x 17$ & \multirow{3}{*}{-} \\
\hline & & & Rial & $1,032.082$ & $1,199.336$ & $32,435.902$ & $7,677.371$ & $1,688.221$ & $26,986.174$ & $31,599.754$ & $2,149.797$ & \\
\hline & & & Share of each sector (\%) & 0.55 & 0.63 & 17.13 & 4.05 & 0.89 & 14.25 & 16.69 & 1.14 & \\
\hline
\end{tabular}

Note: The numbers are in billion Rials (1 USD $\approx 218,000$ Rials (August 2020)).

Table 20. Summary of optimal portfolio results in objective function 2 of the genetic algorithm in Mode 3

\begin{tabular}{l|c|c|c|c|c}
\hline \multicolumn{1}{c|}{ Portfolio } & $\boldsymbol{\alpha}$ & $\boldsymbol{\beta}$ & Risk & Return & Objective function \\
\hline Portfolio 1 & 0.5 & 0.5 & $3,702,141,934,411,100$ & 89,934 & $3,702,141,934,321,170$ \\
Portfolio 2 & 0.25 & 0.75 & $1,756,684,750,585,290$ & 135,139 & $1,756,684,750,450,150$ \\
Portfolio 3 & 0.75 & 0.25 & $5,322,782,579,841,480$ & 44,998 & $5,322,782,579,796,480$ \\
\hline
\end{tabular}

Note: The numbers are in billion Rials (1 USD $\approx 218,000$ Rials (August 2020)). 
Table 21. The contribution of each sector to the objective function 3 of the genetic algorithm in Mode 3

\begin{tabular}{|c|c|c|c|c|c|c|c|c|c|c|c|c|c|}
\hline \multicolumn{14}{|c|}{ Source: Research findings } \\
\hline Portfolio & $\alpha$ & $\beta$ & $\lambda$ & Share of each sector & $x 1$ & $x 2$ & $x 3$ & $x 4$ & $x 5$ & $x 6$ & $x 7$ & $x 8$ & $x 9$ \\
\hline \multirow{5}{*}{ Portfolio1 } & \multirow{5}{*}{0.5} & \multirow{5}{*}{0.5} & \multirow{5}{*}{0.1} & Rial & $1,568.018$ & $1,358.778$ & $3,742.295$ & $3,623.621$ & $2,474.543$ & $5,331.219$ & $21,604.282$ & $30,468.181$ & $3,934.951$ \\
\hline & & & & Share of each sector (\%) & 0.83 & 0.72 & 1.98 & 1.91 & 1.31 & 2.82 & 11.41 & 16.09 & 2.08 \\
\hline & & & & & $x 10$ & $x 11$ & $x 12$ & $x 13$ & $x 14$ & $x 15$ & $x 16$ & $x 17$ & \multirow{3}{*}{-} \\
\hline & & & & Rial & $3,340.209$ & $1,330.411$ & $32,129.693$ & $7,362.044$ & $3,744.861$ & $29,997.902$ & $35,441.738$ & $1,883.343$ & \\
\hline & & & & Share of each sector (\%) & 1.76 & 0.70 & 16.97 & 3.89 & 1.98 & 15.84 & 18.72 & 0.99 & \\
\hline \multirow{6}{*}{ Portfolio2 } & \multirow{6}{*}{0.5} & \multirow{6}{*}{0.5} & \multirow{6}{*}{0.5} & & $x 1$ & $x 2$ & $x 3$ & $x 4$ & $x 5$ & $x 6$ & $x 7$ & $x 8$ & $x 9$ \\
\hline & & & & Rial & $1,231.643$ & 695.455 & $3,167.209$ & $4,638.522$ & 494.614 & $6,821.779$ & $27,517.706$ & $31,034.158$ & $5,412.684$ \\
\hline & & & & Share of each sector (\%) & 0.65 & 0.37 & 1.67 & 2.45 & 0.26 & 3.60 & 14.53 & 16.39 & 2.86 \\
\hline & & & & & $x 10$ & $x 11$ & $x 12$ & $x 13$ & $x 14$ & $x 15$ & $x 16$ & $x 17$ & \multirow{3}{*}{-} \\
\hline & & & & Rial & $3,019.032$ & $2,518.198$ & $33,745.462$ & $6,072.051$ & $1,636.305$ & $27,342.483$ & $32,238.061$ & $1,750.727$ & \\
\hline & & & & Share of each sector (\%) & 1.59 & 1.33 & 17.82 & 3.21 & 0.86 & 14.44 & 17.03 & 0.92 & \\
\hline \multirow{6}{*}{ Portfolio3 } & \multirow{6}{*}{0.5} & \multirow{6}{*}{0.5} & \multirow{6}{*}{0.9} & & $x 1$ & $x 2$ & $x 3$ & $x 4$ & $x 5$ & $x 6$ & $x 7$ & $x 8$ & $x 9$ \\
\hline & & & & Rial & 798.221 & $1,796.945$ & $2,256.561$ & $2,470.434$ & $1,392.117$ & $6,662.983$ & $30,361.845$ & $33,557.273$ & $5,336.569$ \\
\hline & & & & Share of each sector (\%) & 0.42 & 0.95 & 1.19 & 1.30 & 0.74 & 3.52 & 16.04 & 17.72 & 2.82 \\
\hline & & & & & $x 10$ & $x 11$ & $x 12$ & $x 13$ & $x 14$ & $x 15$ & $x 16$ & $x 17$ & \multirow{3}{*}{-} \\
\hline & & & & Rial & $2,789.322$ & $1,818.699$ & $32,212.381$ & $5,996.677$ & $3,613.171$ & $22,167.172$ & $34,831.773$ & $1,274.046$ & \\
\hline & & & & Share of each sector (\%) & 1.47 & 0.96 & 17.01 & 3.17 & 1.91 & 11.71 & 18.40 & 0.67 & \\
\hline
\end{tabular}

Note: The numbers are in billion Rials (1 USD $\approx 218,000$ Rials (August 2020)).

Table 22. Summary of optimal portfolio results in objective function 3 of the genetic algorithm in Mode 3

\begin{tabular}{l|c:c:c:c|c:c}
\hline Portfolio & $\boldsymbol{\alpha}$ & $\boldsymbol{\beta}$ & $\boldsymbol{\lambda}$ & Risk & Return & Objective function \\
\hline Portfolio 1 & 0.5 & 0.5 & 0.1 & {$[103,592,690,7134,640 ; 3,819,187,611,208,800]$} & {$[89,740 ; 90,425]$} & $096,154,779,252,413,1$ \\
Portfolio 2 & 0.5 & 0.5 & 0.5 & {$[972,476,068,666,493 ; 058,431,395,503,845,3]$} & {$[88,893 ; 90,549]$} & $054,018,038,093,062,2$ \\
Portfolio 3 & 0.5 & 0.5 & 0.9 & {$[978,879,529,099,725 ; 3,541,281,833,493,100]$} & {$[90,046 ; 90,703]$} & $056,369,206,140,582,3$ \\
\hline
\end{tabular}

Note: The numbers are in billion Rials (1 USD $\approx 218,000$ Rials (August 2020)). 
According to state 1 shown in Tables 5 to 10 , the largest share belongs to the sectors of greenhouse, agriculture, agricultural services, aviculture, while gardening, natural resources, agricultural commerce and hospitality have the lowest share. Also, the results of Tables 11 to 16 show that in state 2, the largest share belongs to greenhouse, animal husbandry, agricultural services, and agriculture, while the lowest share belongs to agricultural commerce, natural resources, gardening, carpet weaving, and handicrafts. Finally, according to state 3 shown in Tables 17 to 22, the largest share belongs to agricultural services, greenhouse, agricultural machinery, and aviculture, while agricultural commerce, water and soil, gardening, and hospitality have the lowest share. Using the amounts of return and risk in the three states examined, managers' desired models are chosen based on their different estimates of return and risk according to the three above scenarios (and given the importance of each of them).
In the optimum patterns estimated in all states, agriculture (X6), agricultural services (X16), animal husbandry (X15), aviculture (X7), and greenhouses (X12) sectors were assigned the largest shares in their optimum portfolio combination. However, the greenhouse section (X12) has only a small share in the current credit-paying model of the Agricultural Bank according to the greenhouse industry, thus increasing the demand for receiving credits in this section. Therefore, increasing its share is not far from the expectation.

The results showed that in the estimated optimal model, the share of the economic activities fluctuated depending on the strategy used. This finding indicates a difference from Keshavarzi Bank's current credit distribution model, which is caused by the inclusion of risk in the proposed model. The present findings also support previous results regarding the optimal model obtained, as differences were seen in relation to the bank's current credit distribution model (Jao, 1971; Agarana et al., 2014).

\section{CONCLUSION}

The main argument is that in Iran, the high level of deferred receivables of banks indicates a lack of appropriate models for optimal credit allocation. The main objective of this work was to develop a model and solve the problem of optimal credit portfolios. Therefore, multi-objective interval non-linear programming was used to present a portfolio optimization model. This model was finally examined on the data obtained from the Agricultural Bank in Iran. The results showed that the shares of different parts of the genetic algorithm present little deviation from each other and that the optimal pattern obtained from the genetic algorithm is different from the current pattern of distribution of the Agricultural Bank's credits. This subject is considered as risk in the model. The innovation of this research compared to other studies is in considering different economic conditions and risks to intervene the effects of fluctuations and changes in the amount of bank credits.

Therefore, this study tries to provide a suitable model to help managers and bank officials to achieve the best allocation of credits to applicants in different sectors, by considering economic conditions according to limitations of the banking system.

For this purpose, in this research, three different strategies for selecting portfolios (optimistic, pessimistic, and hybrid) were used. The optimally designed model is practical, and financial and credit institutions in other countries can use it to optimally allocate credits by adding and considering their limitations. Managers' desired models are chosen based on their different estimates of return and risk according to the three above scenarios (and given the importance of each of them). The discussed portfolio selection models are not only able to deal with the attitude of the Agricultural Bank managers to various investment strategies, but can also consider the bank's preferences under specific conditions.

Future research is this area includes using other meta-heuristic methods such as particle motion optimization algorithm, colonial competition, etc. Since the definitive model cannot show the actual change 
in overall investment returns and risks arising from changes in expectations of future economic conditions, this can lead to inappropriate investment decisions. Therefore, the use of another model is essential. An interval model can solve this problem. This model, in addition to using historical information on asset returns, indirectly shows the influence of various economic conditions on investment decisions, changing forecasts of future asset returns. Thus, the interval model indicates the importance of investors' experience and knowledge and is therefore more flexible than the definitive model.

\section{AUTHOR CONTRIBUTIONS}

Conceptualization: Abouzar Nahvi, Mohammad Ghorbani, Mahmoud Sabouhi Sabouni, Arash

Dourandish.

Data curation: Abouzar Nahvi.

Formal analysis: Abouzar Nahvi, Mohammad Ghorbani, Mahmoud Sabouhi Sabouni, Arash

Dourandish.

Investigation: Abouzar Nahvi, Mohammad Ghorbani, Mahmoud Sabouhi Sabouni, Arash Dourandish. Methodology: Abouzar Nahvi, Mohammad Ghorbani, Mahmoud Sabouhi Sabouni, Arash Dourandish. Project administration: Mohammad Ghorbani.

Resources: Abouzar Nahvi.

Software: Abouzar Nahvi, Mohammad Ghorbani, Mahmoud Sabouhi Sabouni, Arash Dourandish. Supervision: Mohammad Ghorbani.

Validation: Abouzar Nahvi, Mohammad Ghorbani, Mahmoud Sabouhi Sabouni, Arash Dourandish. Visualization: Abouzar Nahvi, Mohammad Ghorbani, Mahmoud Sabouhi Sabouni, Arash Dourandish. Writing - original draft: Abouzar Nahvi.

Writing - reviewing \& editing: Abouzar Nahvi, Mohammad Ghorbani, Mahmoud Sabouhi Sabouni, Arash Dourandish.

\section{REFERENCES}

1. Agarana, M. C., Bishop, S. A., \& Odetunmibi, O. A. (2014). Optimization of banks loan portfolio management using goal programming technique. International Journal of Research in Applied, Natural and Social Sciences, 2(8), 43-52. Retrieved from https://www.researchgate. net/publication/277566943

2. Aryanezhad, M. B., Malekly, H., \& Karimi Nasab, M. (2011). A fuzzy random multi-objective approach for portfolio selection. Journal of Industrial Engineering International, 7(13), 12-21. Retrieved from https://www. sid.ir/en/journal/ViewPaper. aspx?id=203014

3. Chang T. J., Yang S. C., \& Chang K. J. (2009). Portfolio optimization Problems in Different Risk Measures Using Genetic Algorithm. Expert Systems with Applications,
36(7), 10529-10537. https://doi. org/10.1016/j.eswa.2009.02.062

4. Dubinskas P., \& Urbšienè L. (2017). Investment portfolio optimization by applying a genetic algorithm-based approach. Ekonomika, 96(2), 66-78. https://doi.org/10.15388/ Ekon.2017.2.10998

5. Eletter, S. F., Elrefae, G. A., \& Yaseen, S. G. (2010). Neuro-based artificial intelligence model for loan decisions. American Journal of Economics and Business Administration, 2(1), 27-34. https://doi.org/10.3844/ ajebasp.2010.27.34

6. Gouveia, M. C. B., Neves, E. D. Dias, L. C., \& Antunes, C. H. (2018). Performance evaluation of Portuguese mutual fund portfolios using the value-based DEA method. Journal of the Operational Research Society, 69(10), 1-26. https://doi.org/10.1057/s41274017-0259-7
7. Hao, F.-F., \& Liu, Y.-K. (2009). Mean-variance models for portfolio selection with fuzzy random returns. Journal of Applied Mathematics and Computing, 30, 9-38. https://doi.org/10.1007/ s12190-008-0154-0

8. Jao, Y. C. (1971). Linear programming and banking in Hong Kong. Retrieved from https://hkjo. lib.hku.hk/archive/files/b946b21f3357d77ac3e2da3f8b6644c1.pdf

9. Kamali, S. (2014). Portfolio optimization using particle swarm optimization and genetic algorithm. Journal of Mathematics and Computer Science, 10(2), 85-90. https://doi.org/10.22436/ jmcs.010.02.01

10. Khalifa H. A., \& ZeinEldin R. A. (2014). Fuzzy programming approach for portfolio selection problems with fuzzy coefficients. International Journal of Scientific Knowledge, 4(7), 40-47. Retrieved from https://www.semanticscholar. 
org/paper/FUZZY-PROGRAMMING-APPROACH-FOR-PORTFOLIO-SELECTION-Khalifa-Zei nEldin/665ccf729be085dc3b1f373 afec05ab663d89bb3

11. Kuwornu, J. K. M., Ohene-Ntow, I. D., \& Asuming-Brempong, S. (2012). Agricultural credit allocation and constraint analyses of selected maize farmers in Ghana. British Journal of Economics, Management \& Trade, 2(4), 353-374. https://doi. org/10.9734/BJEMT/2012/2270

12. Lai, K. K., Yu, L., Wang, Sh., \& Zhou, Ch. (2006). A Double-Stage Genetic Optimization Algorithm for Portfolio Selection. Proceedings of the 13th international conference on Neural information processing, 928-937. Retrieved from https://rd.springer.com/chapter/10.1007/11893295_102

13. Lester, A. (2019). On the Theory and Practice of Multifactor Portfolio. The Journal of Portfolio Management Quantitative, 45(3), 87-100. https://doi.org/10.3905/ jpm.2019.45.3.087

14. Lv, L., Zhang, B., Peng, J., \& Ralescu, D. A. (2020). Uncertain Portfolio Selection with Borrowing Constraint and
Background Risk. Mathematical Problems in Engineering, 2020, 1-14. https://doi. org/10.1155/2020/1249829

15. Metawa, N., Hassan, M. K., \& Elhoseny, M. (2017). Genetic Algorithm Based Model for Optimizing Bank Lending decision. Expert Systems with Applications, 80, 75-82. https://doi. org/10.1016/j.eswa.2017.03.021

16. Mohagheghnia, M. J., \& Shirgholami, M. (2013). Optimal bank loan portfolio in Iranian's banks (based linear programming modelling). Research Journal of Finance and Accounting, 4(2), 98 107. Retrieved from https://www. academia.edu/8847181/Optimal_ Bank_Loan_Portfolio_In_Iranians_Banks_Based_Linear_Programming_Modelling

17. Monsef, A., \& Tabatabay, S. M. (2013). Optimum allocation of the bank resources and consumptions using linear planning technique: evidence from Gavamin bank in Iran. Asian Journal of Research in Business Economics and Management, 3(10), 322-334. Retrieved from https://www. indianjournals.com/ijor.aspx?targ et $=$ ijor:ajrbem \&volume $=3 \&$ \&issue $=$ 10\&article $=027$

18. Orlova, E. V. (2020). DecisionMaking Techniques for Credit Resource Management Using Machine Learning and Optimization. Information, 11(3), 144. https://doi.org/10.3390/ info11030144

19. Roodposhti, F. R., Chavoshi K., \& Saber E. (2014). Optimization of portfolio Constituted from mutual funds of Tehran stock exchange using genetic algorithm. Quarterly Investment Knowledge, 3, 217-231. Retrieved from http://jik.srbiau. ac.ir/article_7672.html

20. Tlig, H., \& Dakhli A. (2014). Fuzzy quadratic multiobjective portfolio selection model: a possibility approach. International Journal of Computer Science Issues, 11(2), 56-62. Retrieved from https://www.ijcsi.org/papers/ IJCSI-11-2-1-56-62.pdf

21. Wu, X. L., \& Liu, Y. K. (2012). Optimizing fuzzy portfolio selection problems by parametric quadratic programming. Fuzzy Optimization and Decision Making, 11, 411-449. https://doi. org/10.1007/s10700-012-9126-9 


\section{APPENDIX A}

Table A1. The amount of facilities paid to different sectors

\begin{tabular}{|c|c|c|c|c|c|c|c|c|c|c|c|c|c|}
\hline Row & Economic sector & 2009 & Percentage & 2010 & Percentage & 2011 & Percentage & 2012 & Percentage & 2013 & Percentage & 2014 & Percentage \\
\hline$x 1$ & Natural resources & 140 & 0.2 & 192 & 0.2 & 143 & 0.1 & 175 & 0.1 & 408 & 0.2 & 220 & 0.1 \\
\hline$x 2$ & Gardening & 843,4 & 6.4 & 390,6 & 6.5 & 669,7 & 5.5 & 281,11 & 7 & 907,41 & 7 & 983,71 & 7 \\
\hline$x 3$ & $\begin{array}{l}\text { Carpet weaving and } \\
\text { handicrafts }\end{array}$ & 441 & 0.7 & 689 & 0.7 & 381,1 & 0.8 & 821,1 & 1 & 584,1 & 0.7 & 847,1 & 1 \\
\hline$x 4$ & $\begin{array}{l}\text { Fisheries and } \\
\text { aquaculture }\end{array}$ & 721,1 & 1.7 & 995,1 & 1.7 & 467,2 & 1.9 & 515,3 & 2 & 377,3 & 1.8 & 875,4 & 2 \\
\hline$x 5$ & Hospitality & 391 & 0.6 & 618 & 0.7 & 553 & 0.4 & 238 & 0.1 & 388 & 0.2 & 465 & 0.2 \\
\hline$x 6$ & Agriculture & 511,41 & 20.8 & 171,22 & 23.5 & 709,72 & 19.4 & 563,92 & 18 & 406,34 & 20.7 & 712,35 & 12 \\
\hline$x 7$ & Aviculture & 833,4 & 6.4 & 099,5 & 6.4 & 306,01 & 7.4 & 529,41 & 9 & 945,71 & 8.3 & 068,02 & 8 \\
\hline$x 8$ & Agricultural machinery & 287 & 0.4 & 170,4 & 4.3 & 177,5 & 4 & 149,5 & 4 & 602,9 & 4.4 & 022,41 & 6 \\
\hline$x 9$ & $\begin{array}{l}\text { Agriculture related } \\
\text { industries }\end{array}$ & 106,6 & 9.7 & 759,2 & 3.1 & 836,11 & 8.1 & 044,31 & 8 & 848,61 & 8 & 262,32 & 9 \\
\hline$x 10$ & $\begin{array}{l}\text { Activities unrelated to } \\
\text { agriculture }\end{array}$ & 178,1 & 2.8 & 434,2 & 2.6 & 271,4 & 2.9 & 455,3 & 2 & 345,01 & 5 & 613,11 & 4 \\
\hline$x 11$ & Water and soil & 107,1 & 2.5 & 531,3 & 3.3 & 907,4 & 3.3 & 818,5 & 4 & 505,5 & 2.6 & 494,5 & 2 \\
\hline$x 12$ & Greenhouse & 929 & 1.4 & 670,2 & 2.2 & 362,4 & 3 & 902,5 & 3 & 027,5 & 2.7 & 487,6 & 3 \\
\hline$x 13$ & $\begin{array}{l}\text { Beekeeping and } \\
\text { silkworm }\end{array}$ & 96 & 0.1 & 258 & 0.3 & 352 & 0.2 & 903,1 & 1 & 096 & 0.3 & 384 & 0.2 \\
\hline$x 14$ & Business Services & 444,7 & 11 & 915,21 & 13.3 & 658,3 & 2.7 & 764,11 & 7 & 896,31 & 6.5 & 350,51 & 6 \\
\hline$x 15$ & Animal husbandry & 540,9 & 13.4 & 144,31 & 14.3 & 102,22 & 15.4 & 378,62 & 16 & 000,23 & 15.2 & 896,53 & 41 \\
\hline$x 16$ & Agricultural Services & 756,31 & 20.2 & 033,31 & 14.1 & 835,43 & 24 & 586,92 & 18 & 129,03 & 14.7 & 786,63 & 41 \\
\hline$x 17$ & Agricultural Commerce & 022,1 & 1.8 & 666,2 & 2.8 & 342,1 & 0.9 & 437,1 & 1 & 381,3 & 1.5 & 672,6 & 2 \\
\hline & Total facility & 947,76 & 100 & 832,49 & 100 & 268,341 & 100 & 655,561 & 100 & 032,012 & 100 & 156,352 & 001 \\
\hline
\end{tabular}

Note: The numbers are in billion Rials ( 1 USD $\approx 218,000$ Rials (August 2020)). 
Source: Agricultural Bank.

\begin{tabular}{|c|c|c|c|c|c|c|c|c|c|c|c|c|c|c|c|c|c|}
\hline Period & $X 1$ & $x 2$ & $x 3$ & $X 4$ & $X 5$ & $x_{6}$ & $x 7$ & $x 8$ & $x 9$ & $X 10$ & $X 11$ & $X 12$ & $X 13$ & $X 14$ & $X 15$ & $X 16$ & $X 17$ \\
\hline First half of 2009 & 0.825 & 0.880 & 0.905 & 0.915 & 0.810 & 0.915 & 0.965 & 0.960 & 0.890 & 0.845 & 0.870 & 0.945 & 0.945 & 0.860 & 0.910 & 0.965 & 0.870 \\
\hline Second half of 2009 & 0.840 & 0.895 & 0.910 & 0.920 & 0.815 & 0.910 & 0.945 & 0.975 & 0.895 & 0.850 & 0.890 & 0.950 & 0.940 & 0.875 & 0.915 & 0.960 & 0.885 \\
\hline First half of 2010 & 0.820 & 0.870 & 0.890 & 0.905 & 0.825 & 0.905 & 0.955 & 0.970 & 0.905 & 0.860 & 0.880 & 0.960 & 0.935 & 0.870 & 0.920 & 0.950 & 0.895 \\
\hline Second half of 2010 & 0.830 & 0.875 & 0.895 & 0.900 & 0.820 & 0.910 & 0.950 & 0.980 & 0.915 & 0.865 & 0.885 & 0.955 & 0.925 & 0.880 & 0.925 & 0.955 & 0.890 \\
\hline First half of 2011 & 0.845 & 0.915 & 0.900 & 0.925 & 0.860 & 0.910 & 0.955 & 0.975 & 0.920 & 0.860 & 0.890 & 0.955 & 0.930 & 0.890 & 0.915 & 0.945 & 0.910 \\
\hline Second half of 2011 & 0.860 & 0.940 & 0.930 & 0.910 & 0.875 & 0.915 & 0.960 & 0.980 & 0.915 & 0.870 & 0.900 & 0.945 & 0.935 & 0.900 & 0.920 & 0.960 & 0.920 \\
\hline First half of 2012 & 0.870 & 0.920 & 0.925 & 0.910 & 0.890 & 0.900 & 0.955 & 0.970 & 0.910 & 0.875 & 0.885 & 0.935 & 0.945 & 0.915 & 0.905 & 0.965 & 0.935 \\
\hline Second half of 2012 & 0.875 & 0.930 & 0.920 & 0.915 & 0.885 & 0.905 & 0.965 & 0.970 & 0.910 & 0.885 & 0.890 & 0.940 & 0.940 & 0.910 & 0.895 & 0.965 & 0.955 \\
\hline First half of 2013 & 0.895 & 0.970 & 0.945 & 0.945 & 0.885 & 0.920 & 0.970 & 0.975 & 0.915 & 0.895 & 0.905 & 0.940 & 0.950 & 0.915 & 0.905 & 0.950 & 0.950 \\
\hline Second half of 2013 & 0.915 & 0.975 & 0.950 & 0.940 & 0.890 & 0.925 & 0.975 & 0.980 & 0.920 & 0.900 & 0.920 & 0.945 & 0.955 & 0.925 & 0.900 & 0.955 & 0.955 \\
\hline First half of 2014 & 0.905 & 0.960 & 0.940 & 0.930 & 0.910 & 0.900 & 0.960 & 0.985 & 0.925 & 0.910 & 0.935 & 0.955 & 0.950 & 0.920 & 0.890 & 0.945 & 0.960 \\
\hline Second half of 2014 & 0.910 & 0.965 & 0.940 & 0.940 & 0.900 & 0.910 & 0.970 & 0.980 & 0.930 & 0.920 & 0.940 & 0.950 & 0.940 & 0.930 & 0.895 & 0.940 & 0.970 \\
\hline
\end{tabular}

Source: Research findings.

Table A3. Upper and lower limit of returns in different states (\%)

\begin{tabular}{|c|c|c|c|c|c|c|c|}
\hline & \multirow[b]{2}{*}{ Economic sector } & \multicolumn{2}{|c|}{ State 1} & \multicolumn{2}{|c|}{ State 2} & \multicolumn{2}{|c|}{ State 3} \\
\hline & & Lower limit of returns & $\begin{array}{l}\text { Upper limit of } \\
\text { returns }\end{array}$ & Lower limit of returns & $\begin{array}{l}\text { Upper limit of } \\
\text { returns }\end{array}$ & Lower limit of returns & Upper limit of returns \\
\hline & Natural resources & 0.83 & 0.85 & 0.84 & 0.875 & 0.885 & 0.91 \\
\hline & Gardening & 0.875 & 0.91 & 0.89 & 0.94 & 0.955 & 0.97 \\
\hline & Carpet weaving and handicrafts & 0.895 & 0.91 & 0.9 & 0.93 & 0.935 & 0.945 \\
\hline & Fisheries and aquaculture & 0.905 & 0.92 & 0.912 & 0.93 & 0.932 & 0.942 \\
\hline & Hospitality & 0.82 & 0.855 & 0.83 & 0.875 & 0.88 & 0.905 \\
\hline & Agriculture & 0.9 & 0.91 & 0.905 & 0.917 & 0.92 & 0.925 \\
\hline & Aviculture & 0.947 & 0.955 & 0.95 & 0.965 & 0.965 & 0.972 \\
\hline & Agricultural machinery & 0.96 & 0.968 & 0.962 & 0.977 & 0.98 & 0.985 \\
\hline & Agriculture related industries & 0.892 & 0.91 & 0.9 & 0.92 & 0.925 & 0.93 \\
\hline & Activities unrelated to agriculture & 0.85 & 0.87 & 0.86 & 0.895 & 0.9 & 0.915 \\
\hline & Water and soil & 0.875 & 0.89 & 0.88 & 0.915 & 0.92 & 0.935 \\
\hline & Greenhouse & 0.937 & 0.945 & 0.94 & 0.952 & 0.953 & 0.96 \\
\hline & Beekeeping and silkworm & 0.925 & 0.935 & 0.93 & 0.945 & 0.947 & 0.955 \\
\hline & Business services & 0.87 & 0.895 & 0.875 & 0.905 & 0.91 & 0.925 \\
\hline & Animal husbandry & 0.89 & 0.905 & 0.895 & 0.912 & 0.915 & 0.922 \\
\hline & Agricultural services & 0.942 & 0.95 & 0.945 & 0.96 & 0.96 & 0.965 \\
\hline & Agricultural commerce & 0.88 & 0.915 & 0.89 & 0.94 & 0.95 & 0.965 \\
\hline
\end{tabular}

